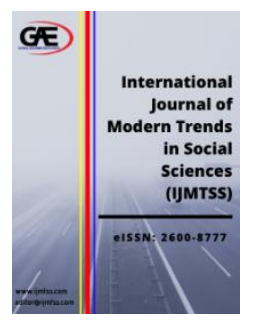

\author{
INTERNATIONAL JOURNAL OF \\ MODERN TRENDS IN \\ SOCIAL SCIENCES \\ (IJMTSS) \\ www.ijmtss.com
}

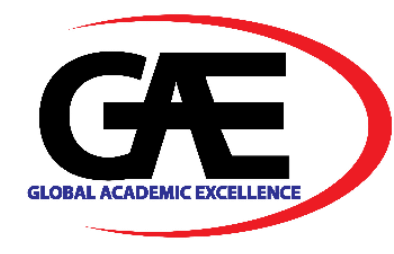

\title{
ASSESSING CROSS-CULTURAL ADAPTATION OF INTERNATIONAL STUDENTS IN IIUM
}

\author{
Hassan Radwan Jamal ${ }^{1 *}$, Saodah Wok ${ }^{2}$ \\ 1 International Islamic University Malaysia \\ Email: hassanradwan.iium@gmail.com \\ 2 International Islamic University Malaysia \\ Email:wsaodah@iium.edu.my \\ * Corresponding Author
}

\section{Article Info:}

Article history:

Received date:05.10.2020

Revised date: 10.11 .2020

Accepted date: 17.11 .2020

Published date: 03.12.2020

\section{To cite this document:}

Jamal, H. R., \& Wok, S. (2020). Assessing Cross-Cultural Adaption of International Students in IIUM. International Journal of Modern Trends in Social Sciences, 3 (14), 47 63.

\section{DOI: $10.35631 / \mathrm{IJMTSS} .314004$}

This work is licensed under $\underline{\mathrm{CC} B Y} 4.0$ (ㅇ)(1)

\begin{abstract}
:
In today's world, many international students from other countries arriving at the host nation are exposed to a wide range of local cultures and values. Malaysia, being a multi-ethnic, multi-religious, and multi-cultural country, is put in a unique position that attracts many international students and foreigners alike. Regardless, many international students experience a clash of cultures between their own and the host's culture, which if not dealt with could have detrimental effects on areas such as studies, social-circles, and self-esteem. Therefore, this study explored the challenges that both undergraduate and postgraduate international students of IIUM encounter when arriving in Malaysia. This study employed a quantitative research design, using the survey method with a questionnaire as the research instrument for data collection. In this study, students aged 21 years old and above were surveyed. This study was based on the theory of cross-cultural adaptation, using the U-curve model that displays each stage of adaptation every student goes through. The findings demonstrated that the cultural stage of adaptation had a positive relationship with the cultural stage of euphoria, the cultural stage of culture shock, and the cultural stage of adjustment. Based on the theory of cross-cultural adaptation as a guide, all the hypotheses were supported in which all relationships were found to be positive and significant.
\end{abstract}

\section{Keywords:}

Adjustment, Cross-Cultural Adaptation, Culture Shock, Euphoria, U-Curve Model 


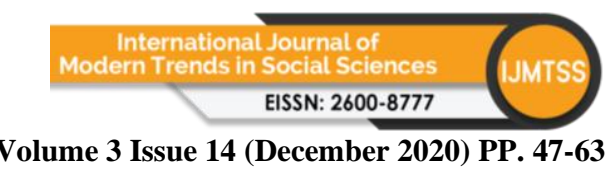

Volume 3 Issue 14 (December 2020) PP. 47-63

\section{Introduction}

\section{Background of The Study}

In this modern era, education is the steppingstone for success. People who are educated tend to have a higher chance of succeeding in life. Many people argue that opportunity comes to those who are educated because getting an education allows them to make informed decisions about what to do. Hence, it is not surprising that higher education has been steadily increasing in terms of its popularity due to the demand of knowledge seekers who seek to study in countries that differ from their own in terms of language, culture, and standard of living (Tahir \& Ismail, 2001).

In today's age, the integration of global society has turned the world into a small village. All around the world, expatriates are in constant search for opportunities to pursue their dreams in hopes of finding a better life. International organizations play a vital role in accelerating crosscultural communication between countries. However, Mohamed (2014) believes that business enterprises are not the only entities responsible for creating a cross-cultural exchange, but academic institutions, too, play a massive role in introducing many international students from different countries and offering a wide range of knowledge and skills.

International students' study and receive their education at hundreds of colleges and universities throughout Malaysia. They contribute to the internationalization and diversity of their communities, universities, and classrooms. International students provide a great way of adding different standpoints and perspectives in classrooms, thus promoting mutual understanding among students. With this being said, education institutions must embrace international students because of what they can offer to the university on various levels. Some of these levels include academic excellence, culture learning, and financial revenue $(\mathrm{Wu}$, Garza, \& Guzman, 2015).

International students also benefit from the host nation, economically and socially. The United States Department of Commerce reported that international students generated over 24 billion dollars into the economy, a staggering number that continues to increase steadily (Quero, 2014). For the locals, international students provide various advantages through their tuition fees and living expenses that they bring in from things like transportation, health insurance, and housing expenses.

Nonetheless, international students in Malaysia have to overcome a wide array of obstacles to fulfill their dreams by undergoing all the adjustment processes. Ang and Liamputtong (2007) stated that international students who are willing to study overseas should come up with an ideal preparation to tackle cultural diversity challenges in the host country they are studying in and make adjustments to settle in and adapt to the local norms and values.

This quantitative research paper aims to examine the academic, social, and cultural challenges that international students have to face when studying in Malaysia, more specifically in International Islamic University Malaysia (IIUM).

\section{Problem Statement}

In a report by the United Nations Education Scientific and Cultural Organization (UNESCO), Malaysia was ranked the $11^{\text {th }}$ most favored place to study by international students (Talebloo, 2013). Students who come to register in the private and public universities are from various continents around the world, such as Africa, America, Europe, Asia, and Australia. Even Copyright (C) GLOBAL ACADEMIC EXCELLENCE (M) SDN BHD - All rights reserved 


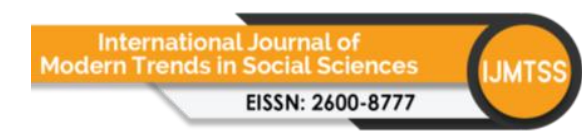

Volume 3 Issue 14 (December 2020) PP. 47-63

DOI 10.35631/IJMTSS.314004

though there are anticipated outcomes to allowing international students, research has demonstrated that international students regularly struggle with culture shock as they migrate and reside in a new country (Hendrickson, Rosen, \& Aune, 2011).

International students encounter various challenges when pursuing their higher education outside their home nation (Bradley, 2000). They face challenges such as unfamiliar living circumstances, language barriers, cultural differences, and personal space. For them to adjust, they must create certain strategies for dealing with culture shock. If Malaysian universities are going to accept students from abroad, then they should address these issues and many more that follow.

Moreover, there is a lack of research conducted on international students and cross-cultural adaptation theory. Most of the research conducted based on the cross-cultural adaptation theory mainly focused on expatriates, migrants, and skilled foreign workers. Therefore, it is imperative to explore how this theory relates to international students studying in Malaysia.

International students in IIUM face a variety of challenges. Studying in a Malaysian university for the first time poses some serious issues for new arrivals. Taleboo (2013) noted that many international students must begin to understand new ways of learning and thinking not only in an academic sense but throughout their stay in Malaysia. Other factors that international students in IIUM must confront are things like the weather, the local currency, the English dialect spoken by the locals, and the native Bahasa Melayu language as well as seeing a variety of other international faces that are different from their nationality. If not done promptly, it could have detrimental effects on not only their academic success but also their mental stability. International students go through several phases, which are honeymoon, culture shock, adjustment, and mastery. Therefore, it is the intention of this study to gauge the level of each phase experienced by the international students of IIUM.

\section{Research Objectives}

The specific objectives of the study are:

1. To find out the level of euphoria, culture shock, recovery, and adjustment among IIUM international students; and

2. To analyze the relationship between euphoria, culture shock, recovery, and adjustment in terms of cultural adaptability among IIUM international students.

\section{Significance of The Study}

International students in Malaysia face some challenges related to culture shock, but it may not affect them equally due to the cultural similarities that some international students share with Malaysia; religion is a notable factor that simplifies the adaptation of some international to the Malaysian culture. Islam, which is the official religion of Malaysia, is crucial for international Muslim students who are studying in Malaysia because it will help them settle in as they can feel at home due to their familiarity with the Islamic culture.

This study is significant for several reasons. It is expected to help international students who intend to study in Malaysia in the future, as it gives students guidelines and a true picture of what their seniors went through. The study covers the challenges faced by international students, the way they tackle the challenges, and the strategies they use to adjust; a combination of all these facets will help them in finding out the true path of cultural adjustment. Further, 
they can obtain sufficient information that will help them in settling in and succeeding in achieving their academic goals in Malaysia.

Many international students suffer from cultural differences between that of their heritage and Malaysia; as a result, they come across many challenges including stress, depression, and anxiety. This study is expected to help international students understand how to make cultural adjustments when studying in Malaysia. Based on this study, students can learn to appreciate the cultural diversity, the probable cultural shock they can face, and how to adjust to fulfill their educational goals.

Future researchers will be able to refer to the findings of this study to obtain a clear explanation of the possible cultural shock that expatriates and international students may face if they decide to study or work in Malaysia. The findings of the study may also be a valuable tool for future researchers due to the contributions to the field of cross-cultural adjustment.

\section{Literature Review}

\section{Challenges of A New Culture}

Lewthwaite (1996) believes that culture shock can be viewed as a phenomenon involving a crisis of personality or identity. An encounter with an alien culture is said to tear down many aspects of familiar bases of one's self, leading to a deprivation of familiarity that they often use as a point of reference. Often, sojourners going through a new environment encounter various obstacles and issues that will be resolved later on. This experience allows them to form new identities that embrace both old and new personalities of their former selves. Similarly, Lewthwaite (1996) sees the culture crisis that many international students go through as necessary for making improvements to their personality for growth and personal development. Culture can be defined as the beliefs, values, and behaviors of where a particular society lives. Ralph Linton (1949) labeled culture as the sum of attitude, knowledge, and habitual behavior patterns shared, which is spread by the members of society. It is the way of life of the people and how they express their feelings and their nonverbal cues and actions to explain certain things. However, this culture is brought to a standstill when traveling to a new environment. Sojourners have to adapt to their surroundings and environment. A similar scenario happens to the international students in IIUM when arriving on campus, who are forced to rethink their personality, leading to the construction of a more integrated and transcultural self.

International students have to experience various stages of cultural changes to adapt to the new culture of the host country. The stages are euphoria, culture shock, culture adjustment, and culture adaptation.

\section{Euphoria}

The euphoria stage, also known as a honeymoon, is the first stage of culture shock. Moghaddam, Taylor, and Wright (1993) found that the experiences that university students feel are tremendously positive as they become captivated with the language, food, and the people in their new environment. It is seen as a great opportunity and chance to learn and admire the changes in a different environment. At that moment, the migration seems like the best decision ever made, often filled with excitement and happiness.

International students at this stage actively meet new peers and make introductions to gain connections (Wang, 2019). They learn about the new cultures and historical places in the host 
country. This stage is often characterized as a honeymoon, an excitement, a fascination, and enthusiasm. Positive perceptions often dominate their mindset. They might have optimistic preconceived notions about how the host nation might look like, the local delicacies, currencies, the language, and the weather.

Taylor (1994) believes that the U-curve is ultimately a learning curve that every new student goes through. He says that the 'honeymoon' stage happens because the sojourners are initially ignorant and oblivious to the cultural norms of the host, leaving them to adapt and acquire sociocultural skills in order to engage in the new environment.

\section{Culture Shock}

This stage is the most challenging and difficult; it is often characterized by feelings of frustration, anxiety, and irritation. Berg (1960) illustrated that culture shock is the anxiety and disorientation that sojourners experience in a cultural transition. They have to adapt to the new culture in aspects such as customs, language, and norms while undergoing psychological discomfort, anxiety, and irritability.

Culture shock is described as the impact of moving from a familiar environment where the culture and value are normal, and the person feels a sense of belonging and normal to another new culture that is unfamiliar to them where things and ways of life are completely different. It usually affects international students who travel abroad either for academics purposes or to live in a foreign country.

Adler (1975) stated that culture shock consists of mainly emotional reactions that result from new different cultural stimuli that have no meaning for one's own culture. It can include feelings of irritability, helplessness, and worries of being contaminated, injured, disregarded, or cheated.

One of the major things that students suffer is homesickness. It is difficult to be separated from beloved ones and the home country. When the homesickness starts, some other elements affect the student who lives abroad. Many students face challenges in adapting to the weather, language, food, and social life, and the combination of all those things can cause unrest and discomfort to international students regardless of the purpose of their stay in the host country.

\section{Culture Adjustment}

Frustrations are often subdued as sojourners begin to feel more familiar and comfortable with the culture, people, food, and language of the new environment. Ward, Okura, Kennedy, and Kojima (1998) noted that navigation becomes easier, friends and communities of support are established, and details of the local language may become more recognizable during the adjustment stage.

Students can slowly understand the language and accents of the locals. However, it is important to note that recovering from culture shock is handled differently by different people. Normally, people have their own unique circumstances, backgrounds, strengths, and weaknesses that need to be taken into consideration (Shu, McAbee, \& Ayman, 2017).

With time and patience, sojourners can experience the positive effects of cultural adjustment such as increased self-confidence, improved self-motivation, and heightened cultural sensitivity. Gradually, international students begin to feel more comfortable in a new Copyright (C) GLOBAL ACADEMIC EXCELLENCE (M) SDN BHD - All rights reserved 
environment and will feel like expanding their social networks and exploring new ideas (Shu, McAbee, Ayman, 2017). As they become more comfortable, they will feel increasingly flexible and objective about their own experience, learning to accept and perhaps even practice parts of the new culture while holding onto their cultural traditions.

\section{Culture Adaptation}

In most circumstances, after weeks or months of wrestling with the emotional stages, the final stage of culture shock is adaptation. Adaptation does not mean that the new cultures or environments are completely understood; rather, it signifies the realization that complete understanding is not necessary to function and thrive in the new surroundings. During the adaptation stage, sojourners have familiarity and can draw together the resources they need to feel at ease.

This is often referred to as the bicultural stage. Bicultural identity is the condition of being oneself with regard to the combination of two cultures. The term can also be defined as biculturalism, that is, the presence of two different cultures in the same country or region. Nguyen and Benet-Martínez (2013) believe that as a general term, culture involves the behaviors and belief characteristics of a particular social, ethnic, or age group. Within a culture, there are cultural effects, the shared behaviors and customs learned from the institutions around them. Cultural effects could include an acceptable way to dress or to act in a certain way.

Regarding bicultural identity, sojourners may face conflicts in assimilating into both cultures and finding a balance between both. They may face challenges in assimilating into the whole, collective culture. Similarly, the sojourners may find it difficult to balance self-identity to the influence of both cultures. Being an international student with identity plurality can be hard mentally and emotionally (LaFromboise, Coleman, \& Gerton, 1993). The different levels of biculturalism can be defined through the way sojourners can simultaneously manage their two selves. The more they alternate between them, the more cognitive complexity they face since they avoid cultural duality and do not practice handling both cultures at the same time. It is through identity integration that they will be able to solve the problem and alleviate the tolls that come with identity plurality.

The U-curve pattern of cultural adjustment observed by Lysgaand (1955) displays the adaptation stages that every student goes through. It is important to note that this U-curve of cultural adjustment varies from person to person. In other words, depending on the personal experiences a person goes through, cultural adaptation might be achieved in a short amount of time, depending on the adaptability and flexibility of the individual. Lysgaand (1955) noted that some people might experience slow and sometimes painful experiences before they can reach the stage of mastery. These factors often depend on their early childhood experiences, such as mingling with people of other races and cultures that can often increase and quicken the cultural adaptation phase, making it a swift and easy experience. 


\section{Conceptual Framework}

Based on the literature review of the relevant concepts of the stages of cultural adaptation, the conceptual framework is visualized (Figure 1).

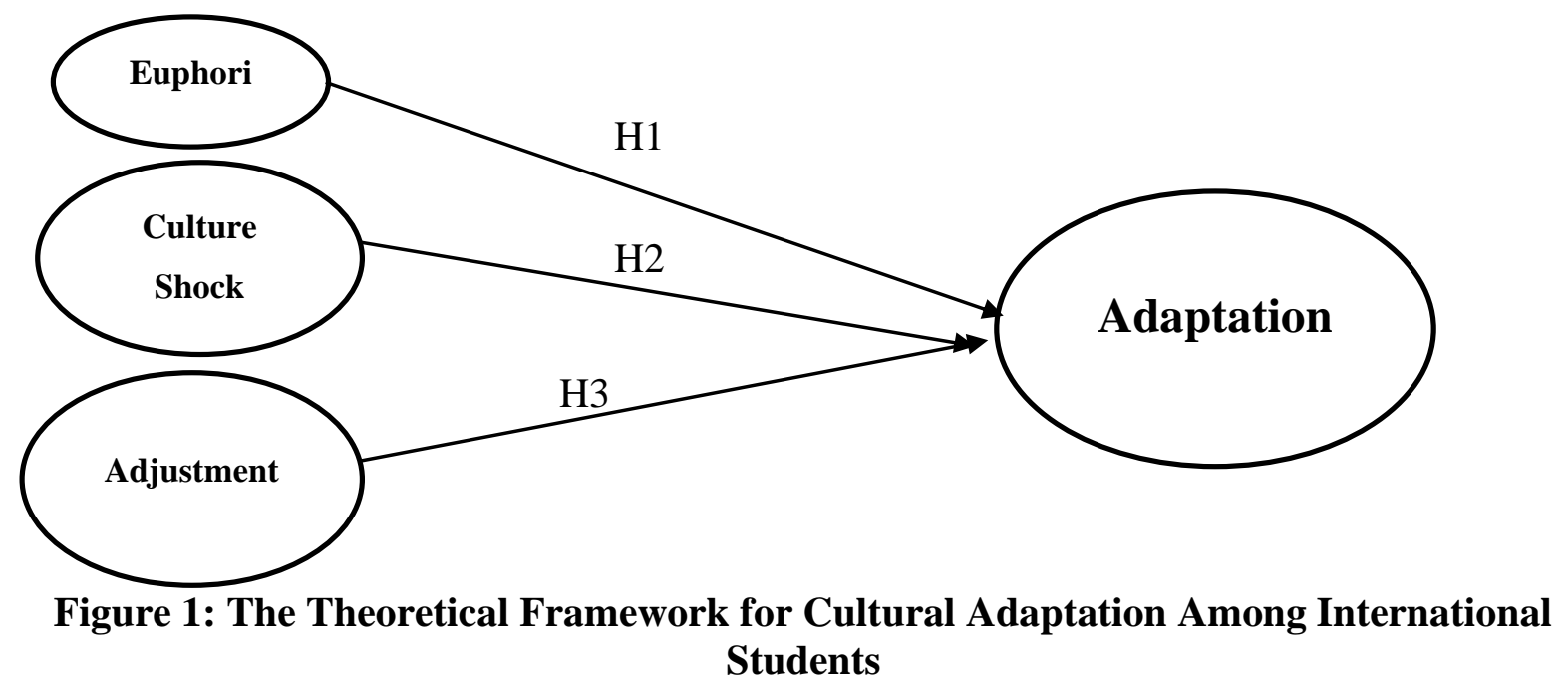

\section{Hypotheses of the Study}

Based on the literature review and conceptual framework, the following hypotheses are formulated. They are:

H1: There is a positive relationship between euphoria and adaptation.

$\mathrm{H} 2$ : There is a positive relationship between culture shock and adaptation.

H3: There is a positive relationship between culture adjustment and adaptation

\section{Research Methods}

\section{Research Design for Data Collection}

This research employed a quantitative research design with the survey method, where a questionnaire was used as the instrument for data collection. Both the self-administered questionnaire and online survey using Google Form were distributed to international students at the IIUM Gombak campus. The self-administered questionnaire was used to ensure that the respondents could complete it on the spot. At that time, the international students were staying within the campus hostels. Given that some of the international students stay outside the campus and with the implementation of the Movement Control Order (MCO) due to the COVID-19 pandemic, the online survey method of reaching them was considered the most appropriate mode for data collection. The data collection process was conducted from April 9 until June 15, 2020.

\section{Population and Sampling Procedure}

The International Islamic University of Malaysia (IIUM) was selected as the locality of the study as there were many international students with varying periods of stay in Malaysia from less than a year to six years or more. There were about 5,000 international students from more than 100 countries studying in IIUM, pursuing either undergraduate or post-graduate studies. A sample of 203 students was obtained through the probability random sampling procedure for the self-administered questionnaire. This sampling procedure gave the population an equal chance of being selected to participate in the study. The participants gave their consent and agreement before the survey was conducted. 


\section{Instrument and Measurement}

The questionnaire consisted of six sections. Section 1 catered for the demographic data of the respondents. Section 2 explored the euphoria stage, consisting of 10 items. Section 3 tapped on the cultural shock stage, also with 10 items. Section 4 asked on the adjustment stage, consisting of 10 items. Section 5 was on the adaptation (acceptance) stage, with 10 items. Lastly, section 6 covered the recommendations for improving intercultural adaptation.

The euphoria stage, cultural shock stage, adjustment stage, and adaptation (acceptance) stage were measured using a 5-point Likert scale ranging from 1 to 5 , where $1=$ strongly disagree, $2=$ disagree, $3=$ slightly agree, $4=$ agree , and $5=$ strongly agree to indicate the respondents' level of agreement. An example of the items for the euphoria stage is "Malaysians welcome me well." The items for the cultural shock stage included "It is hard for me to assimilate to the Malaysian culture." Meanwhile, an example of the items for the adjustment stage is "I am adjusting myself to the Malaysian life." The final stage, which is adaptation (acceptance), included an item that read, "I am comfortable with eating Malaysian foods and dishes."

To calculate the overall percentage of an item, the mean for the item was multiplied by 20 , which is equivalent to $100 \%$ based on the 5-point scale.

\section{Validity and Reliability}

The questionnaire was reviewed and approved by an expert in the field of quantitative analysis and research. The reliability test was conducted using Cronbach's alpha. The data collected from the pilot study indicated that all items for the four variables were reliable and exceeded the minimum Cronbach's alpha value of .70, indicating that the variables were reliable for both the pilot study and actual study. Even though the values of Cronbach's alpha for the actual study were found to be lower than the pilot study results, the items were still reliable. Specifically, the Cronbach's alpha values are: euphoria $(\alpha=.845)$, culture shock $(\alpha=.743)$, culture adjustment $(\alpha=.791)$, and adaptation $(\alpha=.818)$, indicating reliability (Table 1$)$.

Table 1: Means, Standard Deviations, and Reliability of Variables in the Study

\begin{tabular}{|c|c|c|c|c|}
\hline \multirow[t]{2}{*}{ No. } & \multirow{2}{*}{$\begin{array}{c}\text { Variables }(N= \\
\text { 203) }\end{array}$} & \multirow{2}{*}{$\begin{array}{l}\text { No. of } \\
\text { items }\end{array}$} & \multicolumn{2}{|c|}{ Reliability (Cronbach's $\alpha$ ) } \\
\hline & & & $\begin{array}{c}\text { Pilot study }(N= \\
\text { 29) }\end{array}$ & $\begin{array}{c}\text { Actual study }(N= \\
\text { 203) }\end{array}$ \\
\hline 1 & Euphoria & 10 & .965 & .845 \\
\hline 2 & Culture Shock & 10 & .931 & .743 \\
\hline 3 & $\begin{array}{l}\text { Culture } \\
\text { Adjustment }\end{array}$ & 10 & .874 & .791 \\
\hline 4 & Adaptation & 10 & .882 & .818 \\
\hline
\end{tabular}

\section{Data Analysis}

Data were analyzed using Statistical Package for the Social Sciences (SPSS) Version 22. Both descriptive and inferential statistical analyses were carried out. For descriptive statistics, frequencies, percentages, means, and standard deviations were used, whereas for inferential statistics, correlation and regression analyses were conducted to test the hypotheses of the study. 


\section{Findings}

\section{Demographic Statistics of Respondents}

A total of 203 respondents participated in this study (Table 2). Less than two-thirds of the respondents $(62.1 \%)$ were male, while the remaining respondents were female $(37.9 \%)$. More than half of the respondents $(55.0 \%)$ were between 21 and 25 years old, $24.1 \%$ were in the 2630 years old age group, $10.3 \%$ were $31-35$ years old, and the rest $(10.4 \%)$ were 36 years old and older.

Table 2: Demographic Characteristics of Respondents

\begin{tabular}{|c|c|c|c|}
\hline $\begin{array}{c}\text { Demographic } \\
\text { Characteristics }\end{array}$ & Category & Frequency & $\begin{array}{c}\text { Percentage } \\
(\%)\end{array}$ \\
\hline \multirow[t]{3}{*}{ Gender } & Male & 126 & 62.1 \\
\hline & Female & 77 & 37.9 \\
\hline & Total & 203 & 100.0 \\
\hline \multirow[t]{8}{*}{ Age (years old) } & $21-25$ & 112 & 55.2 \\
\hline & $26-30$ & 49 & 24.1 \\
\hline & $31-35$ & 21 & 10.3 \\
\hline & $36-40$ & 14 & 6.9 \\
\hline & 41 and above & 7 & 3.5 \\
\hline & Total & 203 & 100.0 \\
\hline & KIRKHS & 105 & 51.8 \\
\hline & KICT & 28 & 13.8 \\
\hline \multirow[t]{6}{*}{ Kulliyyah } & AIKOL & 21 & 10.3 \\
\hline & KEMS & 21 & 10.3 \\
\hline & KOED & 14 & 6.9 \\
\hline & KOE & 7 & 3.5 \\
\hline & KAED & 7 & 3.4 \\
\hline & Total & 203 & 100.0 \\
\hline \multirow[t]{3}{*}{ Resident } & Inside Campus & 154 & 75.9 \\
\hline & Outside Campus & 49 & 24.1 \\
\hline & Total & 203 & 100.0 \\
\hline \multirow[t]{6}{*}{ Length of Stay in Malaysia } & Less than 1 year & 14 & 6.9 \\
\hline & 1 to 2 years & 49 & 24.1 \\
\hline & 3 to 4 years & 63 & 31.0 \\
\hline & 5 to 6 years & 35 & 17.2 \\
\hline & More than 6 years & 42 & 20.8 \\
\hline & Total & 203 & 100.0 \\
\hline
\end{tabular}

More than half the number of respondents (51.8\%) came from KIRKHS, while $13.8 \%$ came from KICT, followed by AIKOL (10.3\%), KEMS (10.3\%), KOED (6.9\%), KOE (3.5\%), and KAED (3.4\%). More than three-quarters of the respondents $(75.9 \%)$ stayed inside the campus while the remaining $24.1 \%$ stayed outside the campus. In terms of their length of stay in Malaysia, three in ten respondents $(31.0 \%)$ had been staying for 3 to 4 years, whereas $24.1 \%$ had been staying for 1 to 2 years. In addition, more than one-fifth of the respondents $(20.8 \%)$ 
had stayed for more than 6 years, $17.2 \%$ had been in Malaysia for 5 to 6 years, and only $6.9 \%$ had recently come to join IIUM.

\section{Cultural Stage of Euphoria}

The results show that many international students went through the phase of euphoria during their initial stages of arrival in Malaysia (Table 3). On average, many international students were very happy during their initial stage of euphoria in Malaysia $(M=3.221, S D=0.636$, $t(202)=4.951, p=.000)$. They agreed that Malaysians welcomed them well $(74.7 \%)$. Further, they loved being in Malaysia (72.8\%), enjoyed staying in Malaysia (69.1\%), and enjoyed eating Malaysian food and dishes (66.4\%). Similarly, they found the Malaysian language easy to learn and understand (65.8\%), they were learning about the Malaysian culture $(65.4 \%)$, they found it easy to be associated with the locals (63.6\%), and they found the Malaysian history interesting (61.4\%). Meanwhile, items that are negative but significant are that the Malaysian weather is acceptable (52.6\%) and the local people are friendly $(52.1 \%)$, indicating that international students might find the weather difficult to adjust to and they did not find the locals to be friendly.

Table 3: One-Sample $t$-test of For the Cultural Stage of Euphoria

\begin{tabular}{llcccccc}
\hline No. & Cultural Stage of Euphoria $(\boldsymbol{N = \mathbf { 2 0 3 } )}$ & $\boldsymbol{M}$ & $\boldsymbol{S D}$ & $\boldsymbol{\%}$ & $\boldsymbol{t}$ & $\boldsymbol{D f}$ & $\boldsymbol{\rho}$ \\
\hline 1 & Malaysians welcome me well. & 3.739 & 0.915 & 74.7 & 11.504 & 202 & .000 \\
2 & I love being in Malaysia & 3.644 & 0.991 & 72.8 & 9.199 & 202 & .000 \\
3 & I enjoy staying in Malaysia. & 3.458 & 0.981 & 69.1 & 6.654 & 202 & .000 \\
4 & I enjoy eating Malaysian food and dishes. & 3.32 & 1.039 & 66.4 & 4.390 & 202 & .000 \\
5 & I find the Malaysian language easy to & 3.291 & 0.999 & 65.8 & 4.143 & 202 & .000 \\
& learn and understand. & & & & \\
6 & I love learning about Malaysian culture. & 3.271 & 0.985 & 65.4 & 3.918 & 202 & .000 \\
7 & It is easy for me to associate with the & 3.182 & 0.990 & 63.6 & 2.621 & 202 & .009 \\
& locals. & 3.074 & 0.974 & 61.4 & 1.080 & 202 & .281 \\
8 & I find Malaysia's history interesting. & 2.631 & 1.322 & 52.6 & -3.980 & 202 & .000 \\
9 & I find Malaysian weather acceptable. & 2.606 & 1.207 & 52.1 & -4.650 & 202 & .000 \\
10 & The people are very friendly. & $\mathbf{3 . 2 2 1}$ & $\mathbf{0 . 6 3 6}$ & $\mathbf{6 4 . 4}$ & $\mathbf{4 . 9 5 1}$ & $\mathbf{2 0 2}$ & $\mathbf{. 0 0 0}$ \\
\hline
\end{tabular}

*5-point Likert scale whereby 1 = strongly disagree (1-20\%), 2 = disagree (21-40\%), 3 = slightly agree (41$60 \%), 4=$ agree $(61-80 \%)$, and $5=$ strongly agree $(81-100 \%)$.

**Test value is 3

The results imply that, generally, international students experience euphoria during their initial stage of arriving in Malaysia. The results are in line with the previous research indicating that migrants and students experience happiness, intrigue, and a positive-like attitude while discovering new cultures (Moghaddam et al., 1993). However, even though they may be experiencing euphoria, they still find it difficult to adjust to the weather and to associate with the locals.

\section{Cultural Stage of Culture Shock}

Table 4 illustrates that the international students experienced levels of discomfort after a certain period of residing in Malaysia. Overall, they experienced culture shock $(M=3.593, S D=$ $0.524, t(202)=16.114, p=.000)$. The majority of the respondents believed that assimilating with Malaysian culture is difficult (84.5\%) and it is hard to mix with the locals (79.9\%). They also found that the Malaysian weather is unbearable (77.0\%), it is difficult to stay in Malaysia Copyright (C) GLOBAL ACADEMIC EXCELLENCE (M) SDN BHD - All rights reserved 
(73.8\%), Malaysian food is not delicious (73.3\%), and education in Malaysia is difficult $(71.5 \%)$. Similarly, the respondents believed that the locals do not socialize with them $(67.6 \%)$, they had trouble learning the Malay language (65.9\%), and the food prices are expensive $(64.4 \%)$. Above all, they had trouble understanding the Malaysian accent (60.2\%).

Table 4: One-Sample $t$-test For the Cultural Stage of Culture Shock

\begin{tabular}{|c|c|c|c|c|c|c|c|}
\hline No. & $\begin{array}{c}\text { Cultural Stage of Culture Shock }(N= \\
203)\end{array}$ & $M$ & $S D$ & $\%$ & $t$ & $D f$ & $\rho$ \\
\hline 1 & $\begin{array}{l}\text { It is hard for me to assimilate to the } \\
\text { Malaysian culture. }\end{array}$ & & & 84.5 & 17.671 & 202 & .000 \\
\hline 2 & It is hard for me to mix with the locals. & 3.995 & 0.903 & 79.9 & & 202 & .000 \\
\hline 3 & $\begin{array}{l}\text { I find the Malaysian weather to be } \\
\text { unbearable. }\end{array}$ & & & 77.0 & & & .000 \\
\hline 4 & I find it difficult to stay in Malaysia. & 3.695 & & 73.8 & & & .000 \\
\hline 5 & $\begin{array}{l}\text { I do not find Malaysian foods to be } \\
\text { delicious. }\end{array}$ & 3.670 & & 73.3 & 8.066 & & .000 \\
\hline 6 & $\mathrm{n}$ in Malaysia is difficult for me. & 3.576 & & 71.5 & & & .000 \\
\hline 7 & The locals do 1 & 3.38 & & & & & .000 \\
\hline 8 & $\begin{array}{l}\text { I have trouble learning the Malay } \\
\text { language. }\end{array}$ & 3.296 & 1.148 & 65.9 & 3.668 & 202 & .000 \\
\hline 9 & $\begin{array}{l}\text { I find the prices of foods to be expensive } \\
\text { in Malaysia. }\end{array}$ & 3.222 & 1.017 & 64.4 & 3.105 & 202 & .002 \\
\hline \multirow[t]{2}{*}{10} & $\begin{array}{l}\text { I have trouble understanding the } \\
\text { Malaysian accent. }\end{array}$ & 3.015 & 1.200 & 60.2 & 0.175 & 202 & .861 \\
\hline & $\begin{array}{c}\text { Overall Cultural Stage of Culture } \\
\text { Shock }\end{array}$ & 3.593 & 0.524 & 71.8 & 16.114 & 202 & .000 \\
\hline
\end{tabular}

*5-point Likert scale whereby $1=$ strongly disagree $(1-20 \%), 2=$ disagree $(21-40 \%), 3=$ slightly agree (41$60 \%), 4=$ agree $(61-80 \%)$, and $5=$ strongly agree $(81-100 \%)$.

$* *$ Test value is 3

The results imply that international students experience certain levels of culture shock after a certain period of time in Malaysia. This concurs with the previous research done on culture shock; this is due to the fact that they are exposed to mixed feelings of irritation and frustration with the environment around them. Berg (1960) noted that sojourners go through a cultural transition as they are exposed to cultural norms that might bring about discomfort and anxiety. Depending on the upbringing of the individuals and their social circle, the level of culture shock varies from person to person and how adaptive they are to new environments around them.

\section{Cultural Stage of Adjustment}

The results show that the international students adjusted to their environment after staying in Malaysia for some time (Table 5). On average, almost three-quarters of the respondents (73.3\%) began to adjust to their surroundings after some time $(M=3.669, S D=0.486, t(202)$ $=19.606, p=.000)$. Many of the international students agreed that they were adjusting themselves to the Malaysian life $(83.0 \%)$, getting used to Malaysian dishes $(81.0 \%)$, and getting accustomed to the Malaysian prices and currency (76.7\%). Similarly, they were adjusting to the Malaysian weather (73.9\%), learning the Malay language (73.6\%), building relationships with the locals $(73.3 \%)$, adapting to the Malaysian style of education $(72.1 \%)$, respecting local cultural practices (70.3\%), and exploring new places in Malaysia (67.6\%). The lowest item indicates that the international students did not have trouble with the language 
barrier as the Malaysian language is easy to learn and the locals can speak both Bahasa Melayu and English.

Table 5: One-sample $t$-test for The Cultural Stage of Adjustment

\begin{tabular}{|c|c|c|c|c|c|c|c|}
\hline No. & $\begin{array}{c}\text { Cultural Stage of Adjustment }(N= \\
\text { 203) }\end{array}$ & $M$ & $S D$ & $\%$ & $t$ & $D f$ & $\rho$ \\
\hline 1 & $\begin{array}{l}\text { I am adjusting myself to the Malaysian } \\
\text { life. }\end{array}$ & 4.153 & 0.928 & 83.0 & 17.682 & 202 & .000 \\
\hline 2 & $\begin{array}{l}\text { I try to get used to Malaysian foods and } \\
\text { dishes. }\end{array}$ & 4.054 & 0.797 & 81.0 & 18.839 & 202 & .000 \\
\hline 3 & $\begin{array}{l}\text { tting accustomed to the Malaysian } \\
\text { and currency. }\end{array}$ & 3.837 & 1.047 & 76.7 & 11.391 & 202 & .000 \\
\hline 4 & $\begin{array}{l}\text { I am starting to get used to the Malaysian } \\
\text { weather. }\end{array}$ & 3.670 & 0.903 & 73.9 & & 202 & .000 \\
\hline 5 & $\begin{array}{l}\text { I am trying to learn the Malaysian } \\
\text { language. }\end{array}$ & 3.685 & 0.959 & 73.6 & 10.172 & 202 & .000 \\
\hline 6 & $\begin{array}{l}\text { I attempt to build relationships with the } \\
\text { locals. }\end{array}$ & 3.665 & 0.909 & 73.3 & 10.414 & 202 & .000 \\
\hline 7 & $\begin{array}{l}\text { I am adapting to the Malaysian style of } \\
\text { education }\end{array}$ & 3.606 & 0.803 & 72.1 & 10.742 & 202 & .000 \\
\hline 8 & $\begin{array}{l}\text { I try to understand and respect Malaysian } \\
\text { cultural practices. }\end{array}$ & 3.517 & 0.996 & 70.3 & 7.394 & 202 & .000 \\
\hline 9 & $\begin{array}{l}\text { I put effort into exploring new places in } \\
\text { Malaysia. }\end{array}$ & 3.384 & 0.890 & 67.6 & 6.151 & 202 & .000 \\
\hline \multirow[t]{2}{*}{10} & The language barrier is difficult for me. & & & 62.4 & 1.791 & 202 & .075 \\
\hline & Over & 3.669 & 0.486 & 73.3 & 19.606 & 202 & .000 \\
\hline
\end{tabular}

*5-point Likert scale whereby $1=$ strongly disagree $(1-20 \%), 2=$ disagree $(21-40 \%), 3=$ slightly agree $(41-$ $60 \%), 4=$ agree $(61-80 \%)$, and $5=$ strongly agree $(81-100 \%)$.

$* *$ Test value is 3

The results for this study positively support previous research as the international students experienced a transition to the cultural stage of adjustment. Ward et al. (1998) noted that frustration and irritation begin to subside as they begin to adjust to things like navigation, language, and their surroundings. As they start to pick up and tune in to the norms of the local culture, they go through a phase of personal development that combines their own culture and the local culture. This allows them to evolve from the cultural stage of adjustment to the cultural stage of adaptation.

\section{Cultural Stage of Adaptation}

Table 6 illustrates that the overall result $(69.6 \%)$ indicates adaptation of the international students to their surroundings $(M=3.482, S D=0.550, t(202)=12.491, p=.000)$. The majority of the respondents $(81.3 \%)$ agreed that they were comfortable with eating Malaysian food and dishes $(M=4.069, S D=0.761)$. Furthermore, three-quarters of them agreed that they were familiar with the Malaysian economy and prices $(75.1 \%)$, they had many Malaysian friends (74.9\%), they hoped to be a permanent resident someday (73.3\%), and they loved staying in Malaysia (70.8\%). In addition, they had learned to adapt to the Malaysian etiquette $(67.3 \%)$, language $(66.5 \%)$, weather $(65.5 \%)$, and they had explored many places in Malaysia $(64.6 \%)$. The lowest item, which exhibits a negative and significant $t$-value, indicates that they had not built relationships with Malaysians. 
Table 6: One-sample $t$-test of For the Cultural Stage of Adaptation

\begin{tabular}{|c|c|c|c|c|c|c|c|}
\hline No. & Cultural Stage of Adaptation ( $N=$ & $M$ & $S D$ & $\%$ & $t$ & $D f$ & $\rho$ \\
\hline 1 & $\begin{array}{l}\text { I am comfortable with eating Malaysian } \\
\text { foods and dishes. }\end{array}$ & 4.069 & 0.761 & 81.3 & 20.009 & 202 & .000 \\
\hline 2 & $\begin{array}{l}\text { I am familiar with the Malaysian economy } \\
\text { and prices. }\end{array}$ & 3.759 & 0.793 & 75.1 & 13.622 & 202 & .000 \\
\hline 3 & I have many Malaysian friends. & 3.749 & .0873 & 74.9 & 12.211 & 202 & .000 \\
\hline 4 & $\begin{array}{l}\text { I hope to be a Malaysian permanent } \\
\text { resident someday. }\end{array}$ & 3.665 & .0893 & 73.3 & 10.606 & 202 & .000 \\
\hline 5 & in Malaysia. & 3.542 & 1.030 & 70.8 & 7.4 & 202 & .000 \\
\hline 6 & $\begin{array}{l}\text { I have learned to adapt to the Malaysian } \\
\text { etiquette. }\end{array}$ & 3.369 & 0.893 & 67.3 & 5.891 & 202 & .000 \\
\hline 7 & $\begin{array}{l}\text { I am familiar with the Malaysian } \\
\text { language. }\end{array}$ & 3.325 & 1.109 & 66.5 & 4.176 & 202 & .000 \\
\hline 8 & I am used to the Malaysian weather. & 3.276 & 1.044 & 65.5 & 3.761 & 202 & .000 \\
\hline 9 & I have explored many places in Malaysia. & 3.232 & 0.933 & 64.6 & 3.533 & 202 & .001 \\
\hline 10 & $\begin{array}{l}\text { I have built relationships with } \\
\text { Malaysians. }\end{array}$ & 2.842 & 1.123 & 56.8 & -1.999 & 202 & .047 \\
\hline & Overall Cultural Stage of Adaptation & 3.482 & 0.550 & 69.6 & 12.491 & 202 & .000 \\
\hline
\end{tabular}

*5-point Likert scale whereby 1 = strongly disagree (1-20\%), 2 = disagree (21-40\%), 3 = slightly agree (41$60 \%), 4=$ agree $(61-80 \%)$, and $5=$ strongly agree $(81-100 \%)$.

**Test value is 3

The overall result implies that while many international students have learned to adapt to the Malaysian culture, they still hold on to their own cultural values and practices. Williams (2005) stresses that sojourners are able to exhibit a level of personal strength and persistence that allows them to persevere in their environment. While they may have made friends with the locals, they may not have intimate or close relationships with the locals as they hold on to their principles for their own benefit.

\section{The Relationship between Cultural Adaptation and Selected Variables}

Zero-order and bivariate correlations were used to analyze and measure the significant relationships of the cultural stage of euphoria, cultural stage of shock, and cultural stage of adjustment with the cultural stage of adaptation (Table 7).

Table 7: Zero-order Correlations between Cultural Adaptation and Selected Variables

\begin{tabular}{|l|c|c|c|c|c|c|}
\hline $\begin{array}{c}\text { Variable }(N= \\
\text { 203) }\end{array}$ & Mean & SD & Adaptation & Euphoria & $\begin{array}{c}\text { Culture } \\
\text { Shock }\end{array}$ & Adjustment \\
\hline Adaptation & 3.482 & 0.550 & 1 & & & \\
\hline Euphoria & 3.221 & 0.636 & $\begin{array}{c}r=.532, \\
\rho=.000\end{array}$ & 1 & & \\
\hline Culture Shock & 3.593 & 0.593 & $\begin{array}{c}r=.361, \\
\rho=.000\end{array}$ & $\begin{array}{c}r=.354, \\
\rho=.000\end{array}$ & 1 & \\
\hline Adjustment & 3.669 & 0.486 & $\begin{array}{c}r=.386, \\
\rho=.000\end{array}$ & $\begin{array}{c}r=.251, \\
\rho=.000\end{array}$ & $\begin{array}{c}r=.400, \\
\rho=.000\end{array}$ & 1 \\
\hline
\end{tabular}




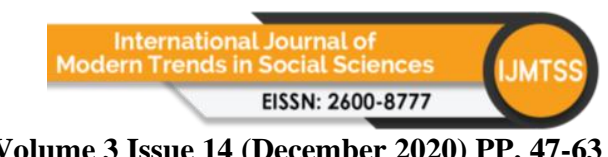

Volume 3 Issue 14 (December 2020) PP. 47-63

DOI 10.35631/IJMTSS.314004

The results indicate significant relationships among all variables. Each of the correlations shows a significant relationship at $p=.000$. There was a moderate, positive, and significant relationship between euphoria and adaptation $(\mathrm{r}=.532, \rho=.000)$; therefore, $\mathrm{H} 1$ is accepted. Additionally, there was a weak, positive yet significant relationship between culture shock and adaptation $(\mathrm{r}=.361, \rho=.000)$; hence, $\mathrm{H} 2$ is accepted. Similarly, adjustment and adaptation had a weak, positive yet statistically significant relationship $(\mathrm{r}=.386, \rho=.000)$; thus, H3 is accepted. Adjustment obtained the highest mean $(M=3.669, S D=0.486)$, followed by culture shock $(M=3.593, S D=0.593)$, adaptation $(M=3.483, S D=0.550)$, and finally euphoria $(M$ $=3.221, S D=0.636)$.

The results show that the relationships of euphoria, culture shock, and adjustment with adaptation were positive and significant. The relationship between euphoria and adaptation was considerably moderate yet significant. Concerning euphoria, the internationals students felt Malaysia a welcoming country, opening its arms to those from outside the country. These findings are consistent with the literature that states that many sojourners generally feel a sense of happiness and a positive attitude when arriving at a new country like Malaysia.

Meanwhile, culture shock and adaptation demonstrated a weak yet significant relationship. This is in line with the previous research that highlighted the challenges that international students go through. Often, culture shock brings an overwhelming amount of emotions such as anger, frustration, and feeling homesick as they begin to get exposed to their surroundings.

Besides, adjustment and adaptation showed a weak yet significant relationship as the international students began adjusting to their surroundings. These findings are coherent with the literature, stating that they start to begin feeling comfortable with their surroundings and the environment. Often, reaching this stage comes from persevering with emotions and people, costing money and time.

\section{Conclusion}

A total of 203 international students participated in the study. Most of their lengths of stay varied from less than 1 year to 6 years or more. This paper highlights the importance of understanding the cultural stages that international students have to go through when arriving at a new country like Malaysia. Many students face many challenges and difficulties before they can reach the cultural stage of adaptation.

In this study, the cultural stage of adaptation was found to have a positive relationship with the cultural stage of euphoria, the cultural stage of culture shock, and the cultural stage of adjustment. With the theory of cross-cultural adaptation as a guide, all the hypotheses were supported in which all relationships were positive and significant. Many of the international students were still young, between 21 and 25 years old and they mainly came from the Kulliyyah of Islamic Revealed Knowledge.

\section{Limitations of the Study}

Throughout this study, many challenges and issues were encountered that could have turned out differently if circumstances were different. A major challenge was conducting this survey during the COVID-19 lockdown in Malaysia. During the lockdown, strict regulations were imposed that needed to be abided to, thus restricting the ability to reach the respondents faceto-face. 
As such, the viable option to complement the self-administered questionnaire was by distributing the survey online. The research was conducted using Google Forms that could potentially affect the statistical data of the research. Nevertheless, these are unprecedented times in history and conducting research during the COVID-19 pandemic shed light on the cultural adaption of the international students. Isolation could have drastic effects on the feelings of euphoria, culture shock, adjustment, and adaptation that would have produced different results if COVID-19 were not present.

Searching for international students was difficult. During the time of research, locals and the internationals locked themselves from the world, adding to an already difficult task of finding international students. In addition, the language barrier was a difficult challenge in measuring cultural adaptation. Many of the international students were newcomers from their country, with little to no English language skills at all; as such, only people who spoke adequate English answered the survey.

\section{Suggestions for Future Research}

Throughout the duration of the research, cross-cultural adaptation theory was used to measure how the international students went through cultural adaptation. Specifically, the U-curve model first observed by Lysgaand (1955) was used with the four stages identified. Further research could perhaps use W-curve models employed by Zapf (1991) that have additional levels of culture shock, adding insights into the levels and experiences of adaptation that international students have to go through.

Future research may also widen the scope to include immigrants or expatriates. This is because they are exposed to different challenges and surroundings that could be different from the experiences faced by international students. Understanding the difficulties, they go through are invaluable as the elimination of challenges provides an opportunity to flourish and further contribute to society and ultimately to the world.

In addition, future research could focus on a larger number of respondents, which would better illustrate the true characteristics and measurements of the study. This is because international students have different levels of education, childhood upbringings, and social settings that could perhaps require a larger number of respondents to truly demonstrate the results and findings.

\section{Biodata}

Hassan Radwan is a post-graduate student at the Department of Communication, IIUM. He obtained his Bachelors in IIUM in Mass Communication, specializing in Public Relations. His research interests are Culture, Communication, Social Media, and Public Relations.

Saodah Wok is a Professor at the Department of Communication, IIUM. She obtained her $\mathrm{Ph}$.D. from University of Wisconsin-Madison, USA in Mass Communication and specializing in Organizational Communication. Her research interests are Organizational Communication, Social Media, Women Studies, Health Communication, and Family Communication.

\section{References}

Adler, P. S. (1975). The transitional experience: An alternative view of culture shock. Journal of Humanistic Psychology, 15(4), 13-23. 
Ang, P. L., \& Liamputtong, P. (2008). "Out of the circle": International students and the use of university counselling services. Australian Journal of Adult Learning, 48(1), 108-129.

Bradley, G. (2000). Responding effectively to the mental health needs of international students. Higher Education, 39(4), 417-433.

Hendrickson, B., Rosen, D., \& Aune, R. K. (2011). An analysis of friendship networks, social connectedness, homesickness, and satisfaction levels of international students. International Journal of Intercultural Relations, 35(3), 281-295

Ishak, A. (2019, September 12). Education Ministry: Revenue from international students expected to grow to RM15.6b: Malay Mail. Retrieved from https://www.malaymail.com/news/malaysia/2019/09/12/education-ministry-revenue from-international-students-expected-to-grow-to/1789792

LaFromboise, T., Coleman, H. L., \& Gerton, J. (1993). The psychological impact of biculturalism: Evidence and theory. Psychological Bulletin, 114(3), 395-412.

Lewthwaite, M. (1996). A study of international students' perspectives on cross-cultural adaptation. International Journal for the Advancement of Counselling, 19(2), 167-185.

Lysgaand, S. (1955). Adjustment in a foreign society: Norwegian Fulbright grantees visiting the United States. International Social Science Bulletin, 7, 45-51.

Mezias, J. M., \& Scandura, T. A. (2005). A needs-driven approach to expatriate adjustment and career development: Multiple mentoring perspectives. Journal of International Business Studies, 36(5), 519-538.

Moghaddam, F. M., Taylor, D. M., \& Wright, S. C. (1993). Social psychology in cross-cultural perspective. New York, NY: W.H. Freeman.

Mohamed, A. M. (2014). Cultural adjustment of international students as expatriates in Malaysia (Doctoral dissertation, Universiti Utara Malaysia).

Nguyen, A. M. D., \& Benet-Martínez, V. (2013). Biculturalism and adjustment: A meta analysis. Journal of Cross-Cultural Psychology, 44(1), 122-159.

Oberg, K. (1960). Cultural shock: Adjustment to new cultural environments. Practical Anthropology, 4, 177-182.

Quero, N. L. (2014). Comparative analysis of intercultural communication apprehension displayed by international students in the us interacting with American students and other internationals (Master's Thesis, Rochester Institute of Technology).

Saunders, M., Lewis, P., \& Thornhill, A. (2007). Research methods for business. London: Pitman.

Shu, F., McAbee, S. T., \& Ayman, R. (2017). The HEXACO personality traits, cultural intelligence, and international student adjustment. Personality and Individual Differences, 106, 21-25.

Tahir, A. H. M., \& Ismail, M. (2001). Cross-cultural challenges and adjustments among expatriates in Malaysia (Doctoral dissertation, Universiti Putra Malaysia).

Talebloo, B., \& Baki, B. R. (2013). Challenges faced by postgraduate students during their first year of study. International Journal of Humanities and Social Sciences, 3(13), 138-145.

Taylor, E. W. (1994). A learning model for becoming interculturally competent. International Journal of Intercultural Relations, 18(3), 389-408.

Wang, B. X. (2019). Guanxi in the Western Context: Intra-Firm Group Dynamics and Expatriate Adjustment. Cham, Switzerland: Springer.

Ward, C., Okura, Y., Kennedy, A., \& Kojima, T. (1998). The U-curve on trial: A longitudinal study of psychological and sociocultural adjustment during the cross-cultural transition. International Journal of Intercultural Relations, 22(3), 277-291. 
Williams, T. R. (2005). Exploring the impact of study abroad on students' intercultural communication skills: Adaptability and sensitivity. Journal of Studies in International Education, 9(4), 356-371.

Wu, H., Garza, E., \& Guzman, N. (2015). International student's challenge and adjustment to college. Education Research International, 1-9. DOI: 10.1155/2015/202753

Zapf, M. K. (1991). Cross-cultural transitions and wellness: Dealing with culture shock. International Journal for the Advancement of Counselling, 14(2), 105-119. 